\title{
2
}

\section{A POLITICAL ECONOMY OF HUMAN RIGHTS VIOLATION IN AFRICA}

\author{
Kunle Amuwo
}

Without being redical or overly bold, I will tell you that the Third World War has already started. The war is tearing down developing countries. Instead of soldiers dying, there are children; instead of millions of wounded, there are millions of unemployed; instead of destruction of bridges, there is tearing down of factories, schools, hospitals and entire economies. It is a war by the United States against the Latin American continent and Africa. A war over foreign debt, one which has as its main weapon, interest — a weapon more deadly than the atom bomb, more shattering than a laser beam,

- Luis Ignacio Silva; the Brazilian Labour Leader ${ }^{1}$

\section{INTRODUCTION}

The foregoing terrifying picture of a highly truncated and dislocated Third World is, it is now common knowledge, a far-cry from the contemporary global rendition of human rights. The latter is equated to economic growth with "some combination of equality, basic needs and self-reliance ... or indeed even the fulfilment of human potential". ${ }^{2}$ Even if one adopts the position of the Commonwealth Governmental Working Group of Experts on Human Rights, according to which human rights is 


\section{Annals of The Social Science Council of Nigeria, No. 7, January-December, 1995}

largely a cultural phenomenon, embedded in the institutions and traditions of each society", 3 economic rationality of logic tends to vitiate the cultural argument.

The point is that whatever the finesse and heuristic value in distinguishing between different typologies of rights - for instance, moral and social rights, such as the right to education and health versus human rights, such as the right to life, individual and group rights and state rights to development, as against individual rights to development ${ }^{4}$ - when the wherewithal to ensure their observance is, $a b$ initio, endangered by a combination of ruinous external and internal factors, what happens? Fundamental human rights become little more than a hollow ritual, observed only in the rhetoric of international organizations, Western statesmen and discredited African rulers.

In this respect, the African charter on human rights, which came into force on October 21, 1986, is generally regarded as a major document in terms of its Africanness or indigeneity as well as in its superiority over comparable bills of rights. The charter subsumes individuals within groups; places the right to development on a legal pedestal; recognizes that the satisfaction of economic, social and cultural rights is the guarantee of civil and political rights; assigns group rights and obligations to family and society; perceives the right to property in a rather "non-ideological" manner in consonance with the heterogeneity of African politico-economic, social and cultural systems. Furthermore, the African Charter recognizes the rights of peoples over their natural' wealth and resources but, then, an extra-African economic imperatival conditionality is inserted, namely, the establishment of a new international economic order. Consequently, whereas Article 22 of the Charter says, rather glibly, that "all peoples shall have the right to their economic, social and cultural development in strict respect of their freedom and identity and in equal enjoyment of the common heritage of mankind", the nature, character and logic of the old international economic order makes this right hollow and of no effect whatsoever.

By the same token, the perceived significance of the African Charter - in terms of capturing the essence of an African conception of human rights as highlighted aboveis rendered almost nugatory by practical statist and leadership-centred actions and policies.

The foregoing does not, however, stop some scholars from talking about internationally-recognized rights. ${ }^{5}$ Are they not the rights the West accords its own people but denied the rest of the world on account of an asymmetrical world order as well as the supreme overall interests of the United States and the other powers? One is here reminded of the so-called "exclusively realist criterion" of the Republican Party Platform of 1980 - articulated in respect of candidate Ronald Reagan and thereafter put into effect under the latter's presidency — for giving foreign aid: 
No longer should American foreign assistance programs seek to force acceptance of American governmental forms. The principal consideration should be whether or not extending assistance to a nation or group of nations will advance America's interests and objectives. The single-minded attempt to force acceptance of United States values and standards of democracy had undermined several friendly nations and has made possible the advance of Soviet interests. ${ }^{6}$

There is a prima facie argument that since the Cold War has come to a seeming end, the improvement doctrine written into the distinction between totalitarianism and authoritarianism may no longer be valid. But it is a phenomenon to be investigated rather than merely affirmed. The Bush government that succeeded the Reagan as no better In halting a decadent gun-boat diplomacy that is rich in the of innovative foreign policy but extremely poor in the delivery of same. ; the Clinton democratic administration has given initial flickers of foreign policy re-direction in favour of a more equitable and fairer world system - in Africa, the long-awaited recognition of the legitimate Santos government in Angola as against the unflinching support for the rebel leader, Jonas Savimbi, hoisted by Reagan and $\mathrm{h}$ presidencies as a "freedom fighter" is a case in point no illusion of a drastic change need be entertained, however.

All the powers, not just the United States, pursue permanent national interests everywhere, camouflaged under high-falutin language of global prosperity and democracy. Howard has, in this respect, argued that all powers "violate human rights as a normal part of internal and foreign policy".?

The international capitalist system that has engendered historical underdevelopment in the Third World is, however, not the sole cause of human rights abuse in Africa. Equally guilty is the sheer unimaginativeness and crass opportunism of domestic political elites. A wretched status quo that is thereby put in place makes $\sim J K$ West and the African leadership to find a common ground for self-centred expression. Again, Howard explicates this phenomenon:

A Western government seriously interested in promoting human rights and development in the Third World would seek above all for ways to empower ordinary citizens... Foreign aid is normally acceptable to ruling Third World elites when it does not upset the balance of power between citizen and state. But ideas of democracy and human rights do frequently upset that balance. Many governments of underdeveloped societies prefer poverty, starvation, and torture to the free debate of their development policies. ${ }^{8}$ 
Before the advent of the "Second Liberation" in Africa — beginning, roughly from 1990 - the sacrifice of human rights was said to be a sine qua non for rapid or accelerated development. Indeed, for almost three decades, the vogue, almost everywhere in Africa, was bad politics, by which I mean a systematized politics of exclusion or wholesale departicipation of a large mass of the populace from internal decision-making processes. This phenomenon led to what Nelson Kasfir referred to, in the 1970s as a "shrinking political arena". In terms of the overall political health of a typical African polity, what we had was analogous to Jack Donnelly's "developmental repression" or Richard Sklar's "developmental authoritarianism".

In concrete terms, the effects of bad politics on African states have proved ruinous on all fronts. The clause in the OAU charter, according to which no state could interfere in the internal affairs of other states, literally comforted petty tyrants and fascist leadership in their political excesses. The Ugandan President, Yoweri Museveni, captured the essence and consequence of this practice at an OAU meeting in the 1980s. For him "while Ugandans perished... the rest of the world kept largely silent ... Ugandans felt a sense of betrayal that most of Africa kept silent". Such passiveness tends, for him, "to undermine our moral authority to condemn the excesses of others, especially South Africa's racist regime. Tyranny is colour-blind and should be no less reprehensible because it is perpetrated by one of our kind". ${ }^{9}$ Neither did the promise of economic development and equality hold, in as much as, to borrow from Pierre Sane, the SecretaryGeneral of Amnesty International, "rights violations are not an inevitable part of modern society. They are the consequence of decisions taken by state officials ...". ${ }^{10}$

Since 1990, a benchmark year, not unlike 1960, a combination of external and internal factors has suggested a reordering of the world order. It is not entirely a new one, but one whose contours and main features include a seemingly new language of diplomacy that is a departure from the unbridled recklessness of a recent past. Part of the effort of the South Commission, for instance, is geared towards a reorientation of development strategies of Third World countries. It takes its cue from the Brandt Commission's 1980 "Program for Survival", which had called for a North-South dialogue capable of facilitating the creation of "a dynamic world in which every country could achieve its own development". But the Commission is emphatic on the imperative of strengthening the economies of the South in order to avoid a dialogue of the deaf and of unequal partners. By so doing, the Commission's recipe of collective self-reliance, as against dependence, will be facilitated. The logic is that "if underdevelopment is to be conquered, the countries of the South must mobilize the potential of their people and their resources for accelerated equitable and sustainable growth". ${ }^{11}$ 
In short, there is an enthusiasm for development, democracy and human rights $\mathrm{m}$ the 1990s and beyond, but with the proviso that development cannot be accomplished without an initial process of humanizing the state and creating "a climate that not merely tolerates dissent, but welcomes it". ${ }^{12}$

Has the demise of the Cold War inaugurated a new world order which ties development with democracy and human rights, one about which many statesmen and scholars have talked so much? ${ }^{13}$ And how far has the new impetus from within civil societies in African countries for innovative and humane politics facilitated this new enterprises? What conclusions, however tentative, can be made now?

What follows - the remainder of this paper — is woven around the foregoing and related questions.

\section{THE WEST, THE BANK AND AFRICA}

We have already alluded to the fact that the West prefers to do business with Africa's most dictatorial and personalist regimes. It pays to so do. It is also very cheap unlike $a$ democratically-elected civilian regime which is often bogged down by the niceties and appurtenances of due process. The World Bank is the West's major instrument for negating sovereignty of African states; seizing initiative of policy-making; increasing foreign investment on the African continent and, consequently, Accentuating poverty.

In his seminal work on the World Bank, Cheryl Payer makes, on this score, at least two salient observations. The first relates to the levels at which the Bank influences, for ill or for good, the lives of the poor in debtor-countries. Payer identifies four levels, namely, individual projects financed by the Bank's loans which have the potentiality of benefitting some poor people; sector level, where due to foreign investment, the Bank's intervention is more likely to deepen poverty; at the "leverage" on the overall thrust and direction of national policies; and the impact of the type of society vis-a-vis the projects. ${ }^{14}$

Payer's second significant observation flows from the above, namely, that the "inegalitarian, corrupt and unjust societies are unlikely to run progressive, beneficial and successful projects". He puts the blame for this on the Bank whose largest borrowers "are notorious for extremely inequitable income distribution and/or violations of human rights". Payer adds that this phenomenon is "a natural consequence of the Bank's preference for lending to governments that offer favourable conditions for foreign investment and of its unwillingness to jeopardize the power of such governments by exerting pressure on behalf of the underprivileged it champions". ${ }^{15}$ 


\section{Annals of The Social Science Council of Nigeria, No. 7, January-December, 1995}

In the pre- "new world order" period, the poor experienced considerable hardship, in spite of the rhetoric of the Bank and the West to abolish poverty. The so-called new world order has done little to move concern beyond mere words and promises. While addressing officials from 172 countries at a World Bank Conference in 1992, its president, Lewis Preston, urged for the revival of the cooperative spirit that made the Bretton Woods institutions a reality after the Second World War. His reason for this might have been more because the "domestic economic problems preoccupy angry electorate" than due to any altruistic motive. Preston then made a plea: "the poor should not be asked to bear the burden of adjustment in the rich countries as well as in their own. The international community must not turn its back on the poor". ${ }^{16}$

Yet the international community has always been indifferent and unsympathetic to the poor. The natural leader of that community, tr. enmeshed, from one government to the other, in rhetorical Reagan, Africa was asked to change her spending priorities and increase investment in human resources development in order to obtain US assistance. The ground rule has, however, been only selectively applied - that is, the principle that the US apply democracy and human rights yardstick hi determining allocation of aid to Africa. Moreover, the US does not favour debt forgiveness doe ID what she claims as her foreign assistance laws which forbid the country from forgiving any interest or principal. The Clinton presidency has, however, written off 228 million dollars, though this is farcry from 228 billion dollars the US is owed. The beneficiaries are, obviously, US allies across the globe. It is also claimed, in respect of the Clinton government, that it would rather prevent mass starvation across die world rather than spend millions of dollars on refugee assistance, famine relief and emergency intervention ${ }^{17}$, but only the future and difficult cases will bring out the difference between a conservative American government and one ran by democrats.

Another rhetoric relates to the concern of the international community to reinforce democracy with sustainable economic development But an enabling environment has, nowhere in Africa, been created. Meanwhile, repressive policies and programmes against Africa, not only by the US and the Bretton Woods institutions, but also by the European Community (EC), have become intensified In Slav 1993, the 12-nation EC agreed to crack down on illegal immigrants: identify and expel foreign students and illegallyemployed residents. Similarly, the EC gave die police and security officers powers over foreigners and racial minorities. ${ }^{18}$ In France, the conservative Interior Minister, Charles Pasqua, has introduced a "zero immigration" policy, meaning each race to itself and God for us all. The multinational corporations are not about to pay fair prices for Africa's commodities and exports - meaning that, rhetoric apart, the mechanisms for impoverishment of the less developed countries are still in place. 
The consequences of the foregoing are that the continent's economic woes have become exacerbated. The debt trap has become more onerous, whilst its servicing continues to adversely affect economic recovery. The continent's access to external funds has also declined. Net financial resource flows nosedived from 22.2 billion dollars in 1990 to 18.4 billion dollars in 1992. According to the 1992 World Bank debt tables, Africa's total indebtedness to the West and Bank is in the region of 178 billion dollars. Furthermore, demand for Africa's exports has reduced and commodity prices have depressed. According to the 1992 World Development Report, there is no real progress in poverty alleviation in the second half of the 1980 s — and this was a time the number of poor people rose almost at the rate of population growth (between 200 and 250 million). ${ }^{19}$

Moreover, virtually all Africa's authoritarian leaders are still intact in power, largely by the grace of the major powers in the West. Some of them have even organized "successful" multiparty elections, which were massively rigged from the preparatory stages, and the crafting of the electoral code through fixing of presidential and legislative elections to the elections themselves. The gross domestic product (GDP) of the world's 36 poorest nations - 25 of which are in Africa alone - still hovers around 250 dollars; the industrial output is less than 10 per cent of the GDP. Similarly, the most illiterate societies in this clime also double as the most heavily indebted, as the case of the Sudan so copiously shows.

In Africa, the right to life was lost by about half a million children in 1988 due mainly to economic stagnation and recession. Current figures cannot be better. By the end of 1991, the West African sub-region accounted for a staggering 78.3 billion dollar debt, representing 45 per cent of the continent's total debt stock.

In the same way the Bank and the Fund now dictate macroeconomic and monetarist policies for Africa, the West is also increasingly using its aid to Africa as a lever to increase trade surplus. A British member of Parliament (MP), Michael Meacher, has recently revealed the British variant of that network. For him, "in 1991, no less than 74 per cent of Britain's bilateral aid commitments (amounting to nearly $£ 1$ billion) were tied to British goods and services. Moreover, of the further $£ 1$ billion of British aid committed to multilateral agencies, such as the EC or World Bank, every $£ 1$ is expected to yield $£ 1.40$ spent on British goods". ${ }^{20}$ Aid fatigue has supplanted aid compassion and the resultant effect is the virtual termination of traditional aid. it is business as usual, particularly with political and military elites that are totally out of tune with their people's realities. The West imposes the requirement of good government and respect for human rights only as an attempt to impress critical segments of domestic civil societies. 
It is instructive to note that the West and its financial institutions say little about the excesses of military budgets, yet that is one sector where human rights are grossly violated. Whenever these institutions outline their conditionalities, they never make any reference to such budgets. They hide under the notorious provision of noninterference in the internal affairs of a sovereign state. It is clear, however, that when they face the choice "between tanks and tractors", the Bretton Woods institutions choose the former. Kola Adesina talks in this respect, about "the debilitation and destruction wreaked on Mozambique, Angola, Ethiopia and Somalia by weapons proliferation aided by Western nations and arms barons" 21

Money laundering by African rulers in major European financial and banking houses was, until very recently, hardly discouraged. Even now that Swiss banks perhaps the most notorious of them all in terms of their enveloping secrecy — are seemingly opening up, there is the need for cautious optimism. According to a view, Africa's response to this foreign policy thrust by Europe "should not be debt rescheduling but the recovery of the billions stashed away in foreign banks". ${ }^{22}$

The highly visible phenomenon of refugee problem of the continent is also a consequence of mass violation of human rights of which Burundi, Malawi and Mozambique are the archetypes. ${ }^{23}$ The sum total of Africa's international decapitation and exploitation through human rights violation is that the continent is gradually, perhaps surely, "slipping off the map of the world's concerns".- ${ }^{4}$ a process that commenced in the 1980s.

\section{AFRICAN CIVIL SOCIETIES AND THE NEW LIBERATION THEOLOGY}

If 1990 is taken as the beginning of a new lease of political — and related — life in Africa, 1992 may be said to be a year of last-line efforts by authoritarian regimes to regain lost ground. Kaye Whiteman described 1992 as "the year of rear-guard actions by unreconstructed dictators". ${ }^{23}$ While the likes of Presidents Mobutu Sese Seko and Gnassingbe Eyadema ought not to be lumped together with Presidents Paul Biya and Houphouet-Boigny on account of differences in dictatorial tactics, there is, in reality, little to choose between the two categories of leaders.

A Belgian journalist, Colette Braeckman. in her book on Mobutu, Le Dinosaure, characterized the latter in ways that the aforementioned leaders, and others of their ilk, find generous expression. Dinosaurs are "vast in their strength, brutish in their reactions, struggling at all costs to survive but ultimately doomed because of their inability to adapt ${ }^{26}$ 
Beginning from 1990, the different civil societies in Africa — particularly in Francophone Africa where systematic human rights violations were more pronounced on account of monoparty and personalist political systems - commenced full-blown political struggles to combat two, not altogether unrelated, public policies. These are the Structural Adjustment Programme (also called Economic Recovery Programme) and massive corruption hi the public realm. The latter had, everywhere, deepened the crisis of the state; the activities of political, economic and bureaucratic elites and those of $\mathrm{Mr}$ - as well as Mrs - President extremely injurious to public economic, financial and moral health. Corruption also constitutes a menace to fundamental rights.

The Ivorian jurist, Hyacinthe Sarassoro, has, in fact, equated corruption to genocide, in so far as it kills a people instalmentally or incrementally. For him, "corruption constitutes an infringement of human rights in so far as it exacerbates the public debt of African States and the deepening of the gap that exists between industrial and nonindustrial countries". He reasons further that Africa's basic human rights are being violated by her politicians and the latter's bankers. Such rights are violated when money meant for providing fundamental needs of citizens are diverted by African rulers to European banks and when money earmarked for agriculture is diverted to Swiss or other banks leading to mass starvation. ${ }^{28}$

Economic hardship has brought in its trail a plethora of social and political problems. Everywhere, there is growing unemployment; workers' salaries and students grants are in arrears of several months; social infrastructures and services have become either grossly unsatisfactory or vanishing categories. As the economy worsens and the criticism of the civil society becomes more trenchant, governments have tended to react more and more negatively. When the clamour, pressures and struggle for democratization and humane governance reached unbearable proportions, the various leaders craftily and skillfully adjusted their personalist rule to the requirements, often Western-imposed, of multipartyism. It is the same West that has aided and abetted the leaders to virtually empty multipartyism of all its virtues, values and contents. Today, political pluralism has become almost an empty shell.

The West had, ab initio, seized political initiative from Africa's civil societies, calling the shots for the ensuing opening up of the public, political and democratic space. Such opening is necessarily restrictive and limited. The West did so in order to protest her primordial and permanent interests, for this is what matters and not Africa's development. At the Francophone Summit in Mauritius in October 1993, Mobutu Sese Seko featured prominently, even though he had, just before the Summit, ran into problems with the three Western nations hi control in Kinshasa - the US, 


\section{Annals of The Social Science Council of Nigeria, No. 7, January-December, 1995}

France, Belgium - - on account of his anti-democratic and anti-human rights activities. He was only gently warned to desist from holding premature elections as previously announced by him for December $1993^{29}$. Of course, the elections never held until he was kicked out by rebel forces led by Laurant Kabila in May, 1997

Courted, cajoled and used by the West, even though hated by his own people, Mobutu always found favour with France. Less than a month after the French ambassador in Zaire was assassinated in early 1993, during an anti-Mobutu protest, French authorities granted Mobutu permission to see his Riviera dentist. The permission is not out of character. France and the US are, rhetoric to the contrary notwithstanding, often open supporters of repressive regimes in Africa. Contrary, therefore, to certain views tying democracy in Africa to the benevolence and altruism of the West, it is Africa, not the West that will save the continent. Thus, "... one hopes there are few illusions in Africa about how greater democracy is going to be achieved other than with Africa's own resources and through Africa's own struggle. French sentimentality about democracy may in the end be a hindrance because of the illusion it can create"..$^{30}$

The consequence of the West's deep romance with authoritarian leaders and its lipservice to issues of democracy and human rights is that efforts of vibrant segments of the civil society towards political liberation are often thwarted. It has been suggested that "the vast majority of the African people accept a democratic destiny, not least because it guarantees both human rights and participation in economic development policies". ${ }^{31}$ But even when the vast majority of the people do not understand the details of democracy or are wholly indifferent to the historic duty of their vanguard organizations and spokesmen to educate them as to the essence of democracy - in terms of change in the groundnorms and rules of politics, governance and succession - it does not thereby follow that democracy should be abandoned. In other words, "the cultural framework within which

political forces operate must become more accommodating and adaptable". ${ }^{32}$ The foregoing will matter little as long as the West does not want it to matter - except and unless spirited combats are put up by politically aware and assertive groups in the civil society.

The reality on the ground, for now, suggests that such a combat, if it has started, still has a long future before it; nor will it be an easy one.

\section{The Ivory Coast}

Late Houphouet-Boigny's Ivory Coast is France's most celebrated ex-colony in the West African sub-region. It used to be Africa's most significant economic "success" story until the middle of the 1980s. Since then, however, the economic fortunes of the country have considerably nose-dived. The economic situation is very sombre; 
The miracle has become a huge misery. It was common knowledge even before the demise of Houphouet-Boigny that the economy, not the political opposition, is the nemesis or achille's heel of an overly dependent Ivorian government.

Boigny left behind a huge debt of some 17 billion US dollars, serviced by 40 per of export earnings. The latter has also been dwindling due to slump in world t prices of cocoa, coffee, cotton - which, altogether, account for over 80 per cent of revenue. From 1985 to 1990, cotton earnings had declined by 44 per cent; while the GDP fell in real terms in 1991 for the fifth consecutive year. Added to this was a local debt portfolio of about 1,200 billion FCFA. France, that used to pick debt service bill sometimes to the tune of 350 million dollars a year, has developed debt-sorvicing fatigue. Yet it was in the midst of all this that Boigny built a Catholic Basilica, second only to the Vatican's, at the cost of 200 million dollars, allegedly from personal funds.

The Ivoirian government suddenly found itself unable to discharge its most elementary function of paying workers' salaries. It could also not honour bursary obligations to university students. The government was constrained to accept a new reform package of the Bank and Fund, whose major elements are the following: reduction of salaries of public sector workers; further reduction of the number of public workers which had already been reduced from 110,000 to 90,000; and the devaluation of the CFA franc which came effectively into force in January 1994.

Academics, workers and students, as well as the opposition political parties found a common ground of operation to fight an unpopular Boigny government to a standstill. While the immediate background of the liberation combat was harsh economic and budgetary measures, the latent reason was the highly controversial multiparty election, the first in Ivorian history, widely believed to have been rigged in October 1990 in favour of Houphouet-Boigny. The opposition leader believed to have won that election, Laurent Gbagbo, leader of the Front Populaire Ivorien, his wife and major supporters as well as Francis Wodie, leader of the Parti Ivoirien du Travail, Rene Degui Segui, SecretaryGeneral of the Ivorian Human Rights league (LIDHO) and known activists of the banned, but visible and active Federation Estudiantine et Scolaire de Cote d'lvoire (FESCI) have, since 1990, been at the receiving end of the intolerance of a political power at its tether's end and on steep decline.

When the main teachers' union and principal lecturers' association fought authorities over pay conditions of service and political interference in internal academic affairs, security forces forcefully entered students' hostels in Yopougon in May 1991. It was the above-groups that were blamed for the ensuing riots and violence. While the civil society had evidence to show that unemployed thugs 


\section{Annals of The Social Science Council of Nigeria, No. 7.January-December, 1995}

(loubards), used, according to students, as agents provocateurs and surprising shock troops for the president had caused the mayhem, the authorities imprisoned Gbagbo and his men and arrested no fewer than a hundred of his supporters. Mute was the word from Paris.

But by far the major problem since a multiple press was allowed to blossom has been the gagging of independent media. By 1992, the Ivory Coast had eight dailies. While some analysts lament the hero and praise worship syndrome of both government and opposition press, the former was stirred enough to combat the latter. Government created two newspaper, La Democratic and Le Patriote in addition to the existing two, that is, Franternite-Matin and Ivoir-Soir. The opposition countered with La Voie et Le Nouvel Horizon.

Government prevailed with a press law which stipulated still penalties/zr tgise wgi iffebd "state interest" and fairplay. Opposition journalists and newspaper barons who ignored the law were jailed, while seven others suffered various punishments. Government also brought media practitioners under one union ostensibly to "enable them observe professional ethnics", whatever that means. It remains to be seen how the new successor government of President Henry Konan Bedie would relate to the opposition.

\section{The Cameroon}

While, as already alluded to, President Paul Biya may not be a dinosaur in the fashion of Mobutu and Eyadema, he is generally believed to be an unpopular man who loves the "comfort of authoritarian power". According to a respected view,"... (Biya) fell asleep in the comfort of authoritarian power ... He was an excellent underling, but he never knew ho to lead men". Again, "his silence when implicated in financial scandals, his taste for material goods, his bias for Beti people who occupy key posts, his clear disinterest in public matters - in 1990, he presided over only two cabinet meetings and in 1991 only one - make this lover of golf an unpopular man". ${ }^{33}$

As with the National Assembly elections of March 1, 1992, the first multiparty elections in over 25 years, the Biya government also rigged the presidential elections of October 11 same year. These were two painful phenomena for the civil society insofar as it took a six-month long ghost town operations in 1991 to force the President to embrace political pluralism. Using divide and rule tactics, President Biya granted license to as many as forty-five political formations to play politics. Matters were not helped by the fact of a deeply divided opposition which, notwithstanding rhetoric of unity, sought individual self-expression and assertion. Leading political personalities and groupings at the starting blocks were the following: John Fru Ndi of the Social Democratic Front (SDF); ex-minister Samuel Eboua's National Union 
For Democracy and Progress (UNDP); Movement des Paysans du Cameroon (MPC); Parti de la Solidarite du Peuple (PSP)

As in Gabon and Guinea in 1993 a partial etat d'urgence was instituted during the announcement of the presidential results on October 25,1992. Fru Ndi, believed to have won the election - even though the Supreme Court's election announcement gave Biya 39.9 per cent of the votes and Fru Ndi, candidate of a coalition of 30 parties, 35.9 per cent - was put under house arrest; his supporters arrested and his North-Western home region, Bamenda, put under security surveillance.

The Us and Germany reacted not to the electoral result but rather the house arrest of Fru Ndi by suspending aid to Cameroon. The EC and France expressed concern, "although as usual, it (was) not clear where France (stood) on the matter". ${ }^{34}$ in general, the West's reaction to such issues are predictable and uniform: it gently reprimands or threatens sanctions; sometimes it actually slams them on a friendly, if "offending", government. By the time the internal dust settles, however precariously, a return to business as usual, is quickly effected.

The aftermath of the rigged presidential elections has seen a multiple, vibrant and rigorous press hardly giving the Biya government any breather. The government's reaction was to put in place a blanket censorship system before publication. This routine continuous censorship is complemented by a law on mass communication that is, for all practical purposes, highly restrictive of freedom of expression and information. Press harassment - both physical and legal — has been on the increase since October 1992. Leading dailies and magazines in the 100-odd membership have suffered considerably under an overbearing Biya regime. The titles in question include $L$ 'expression Nouvelle Challenge Nouveau, L'Ami du peuple and La Messagere.

Some of the legal actions merit a mention. One, in April 1993, two journalists of L'expression Nouvelle were sued by government for libel. For writing an article on how senior customs officers were involved in fraud, they were each jailed six months and fined 150,000 CFA. The same month, two journalists of $L$ 'Opinion were sentenced to eight months imprisonment and a fine of 500,OOF CFA for publishing "false news" namely a mere reporting of allegations by opposition parties that an ex-Prime Minister had made illegal payments to another politician.

Finally, three journalists were suspended from work for asking "embarrassing questions" from the Communications Minister during a Press Conference. ${ }^{35}$

Aside harassment of the press, the Biya government has also resorted to a copious process of marginalizing the opposition. This is easily seen in the use of television air time in spite of the law guaranteeing the time on public radio and television to political parties. During the presidential elections, the Cameroon People's Democratic 
Movement (CPDM), the ruling party, was accorded 142 minutes as against 12 minutes shared among six opposition candidates.

\section{Zaire}

An insight into the fabulous wealth of Sese Seko Mobutu is highly revealing: at least 51 Mercedes Benz cars; a 32-bedroom villa in Switzerland with a permanent staff of 32 servants. The man's personal and family wealth has been described thus: "the debt of (Zaire) is 5 billion dollars and coincidentally, that is the estimate of how much General Mobutu and his family have stolen from Zaire". ${ }^{36}$

No man with such a fabulous wealth will give up power without a big fight. While the civil society has been pressurizing Mobutu to either democratize or close shop, the United States keep on saying that he has a political role to play, that he needs to control the army; yet, Mobutu uses the same military as well as the Special Presidential Division (of the Civil Guard and Police Force), mainly from his Ngwandi tribe and Central African Republic, to put down civil protests at will.

An invaluable opportunity to limit the excesses of the Mobutiste state was missed in the Sovereign National Conference (SNC). The conference which lasted one and a half years, ending in December 1992 had, inter alia, made a ceremonial Head of State of Mobutu. His rnain rival, the opposition-elected Prime Minister, Etienne Tshisekedi was given full powers with the Haute Conseil de la Republique (HCR). Mobutu succeeded in derailing the conference decisions. He refused - like Eyeadema - to obey injunctions, an action that spurred mass protests from January 1993.

The Zairian case has been an eye-opener to the West: Sovereign National Conference is a dangerous monster that should never again be allowed. With a 3000 per cent inflation; 250 political parties in a Union Sacre (Holy Union); frequent army mutinies; food as a vanishing category prompting both government and opposition to seek, in Washington, food, pharmaceutical and other basic necessities after the riots of September 1991; an economy that makes "millionaires" out of poor workers etc; the Zairian nation is in total ruins.

A leading Zairian scholar, Georges Nzongola Ntalaja,believes that the opposition, and not just the West, is to be blamed. For him:

the conclusion to be drawn from the Zairian experience is that rather than seeking compromise agreements that dictators will never honour, a Zairian type situation requires that a dictator be pressured into stepping down. ${ }^{37}$ 


\section{BY WAY OF CONCLUSION}

We have tried to show in the foregoing, that both international and domestic factors have railroaded Africa away from development, democracy and human rights. Any analytic schema that emphasizes the one at the expense of the other is no more than a partial explanation of what is a veritable complex socio-political phenomenon. It would appear, however, that the international component of the schema is more important than the domestic one.

If the West props up Africa's dictators, the response of Africans is to stand up against that foreign policy posturing in a principled and sustained manner. This kind of response has been long in coming, but it seems the first steps have only recently been taken.

In an open letter, signed by over 300 US-based Francophone African leaders in January 1994, and addressed to France and French political leaders, a new generation of Francophone leaders complained about Paris' "deplorable policy and attitude in Africa". The signatories oppose France's double standards, and her tendency of speaking from both sides of the mouth: rhetoric about democracy and support for despotic regimes and leaders. While reminding France of her revolutionary history and its important legacy of human rights, the group invited France "to espouse a policy that serves not only the interests of the African peoples but also the well-thought out interests of the French people".

By the same token, the French people are enjoined "to exert a tremendous pressure on their political leaders to adopt political practices and an African foreign policy deserving of our times", that is, a foreign policy that terminates forthwith France's "tenacious support of dictatorial African regimes". 38

This is a message that can be addressed also to America and the rest of the West. It is also a message that the rest of Africa-Arabophone, Hispanophone, Anglophone,

Lusophone - can also send to the West, to their political leaders as well as consider for self-critique and sustained political struggles.

\section{NOTES}

1. $\quad$ Cited in "Darwinism rules okay?" West Africa (London), 2-8 August 1993, p. 1335.

2. Rhoda E. Howard "Human Rights, Development and Foreign Policy" In David P. Forsythe (ed.) Human Rights and Development. International Views (Basingstoke and London, 1989)p.215.

3. See Commonwealth Secretariat Report of the Commonwealth Government Working Group of Experts on Human Rights, 1990, p.4 
38 Annals of The Social Science Council of Nigeria, No. 7, January-December, 1995

4. Cf Osita C, Eze, African Concept of Human Rights (Lagos: Federal Ministry of Justice, 1992), pp. 2-3.

5. An Example is David P. Forsythe in the Introduction to his edited work, op. cit.

6. Cited in Michael Stohl, D. Carlton, M. Gibney and G. Martin "US Foreign Policy, Human Rights and Multilateral Assistance", in Ibid, pp. 200-1.

7. Howard, op. cit, p.223.

8. $\quad$ Ibid

9. Cited in Amnesty International. A Quid to the African Charter on Human and People's Right, (London 1991), p.7

10. See Pierre Sane. "An Agenda for Action" West Africa, 20-26 December 1993, p.2294.

11. Cf The Challenge to the South - The Report of the South Commission. 1990.

12. Ibid

13. See, for instance,' Jide Owoeye (ed.) Understanding the New World Order (Tbadan: College Press, 1993).

14. CherylPayer, The World Bank, A Critical Analysis (New York and London: Monthly Review Press, 1982), p.20ff.

15. Ibid. Payer argues that whilst the Bank claims that its loan decisions are always a reflection of economic criteria, blatant economic mismanagement is the norm of many borrowers who are highly favoured. Example, Mobutu's Zaire; Marcos' Philippines and regimes in Chile, Turkey and Indonesia in the early 1980s, p. 43ff.

16. See West Africa 5-11 October, 1992, p. 1672.

17. See "Clinton's New African Era", West Africa 3) May - 6 June 1993, p.899.

18. $\quad \underline{\text { Ibid. }}$

19. Cf Brian Moyo "Africa's gloomy economic crisis", West Africa

20. See West Africa, 2-8 August 1993, p.1344.

21. See Kola Adesina "Between tanks and tractors" in ibid, passim. 
22. Desmond Davies "Can't Pay, Shouldn't Pay" Ibid, pp. 1339-40.

23. There are no fewer than 700,000 Burundian refugees in Rwanda, Tanzania and Zaire; Some 1.05 million Malawians, third largest refugee population globally scattered all over the world; and a million Mozambican refugees in Malawi.

24. $\quad$ Cf "A Painful Year", West Africa, 21 December 1993 - 9 January 1994, p.2334.

25 K. Whiteman "Francophone Africa: Democrats and Dinosaurs", West Africa, 28 December 1992 -10 January 993, p. 2236.

26. Ibid.

27. Sarassoro cited in Desmond Davies, op cit.

28. Ibid.

29. $\quad$ See "Mirage in Mauritius?", West Africa, 25 -31 October 1993, p.1906-7.

30. $\quad$ See "French Elections and Africa", West Africa, 8 - 14 March 1993, pp.336-7.

31. Cf "Tracking the Transition", West Africa, 25-31 May 1992, p.869.

32. Ibid.

33. This view is of Le Monde, France's leading liberal daily. Cited in T.M. Azonga "Robbed of Victory", West Africa, 2 - 8 November 1992, pp. 1870-1.

34. See "Fight for Survival", West Africa, 28 December 1992-10 January 1993, pp.22356.

35. Cf T.M. Azonga "Catalogue of Woes", West Africa, 1 - 8 August 1993, pp.1346-7.

36. This is Susan George's Assessment in "A Fate Worse Than Debt" as in West Africa, 2 - 8 August 1993, p. 1339.

37. See G. Nzongola-Ntalaja "Mobutu's Dirty Tactics" in West Africa 27 December 1993-9 January 1994, p.2345.

38. See Desmond Davies "Francophone: Fighting Back", West Africa, 31 January - 6 February 1994, pp. 174-5. 